\title{
Detection of Type 1 Ostreid Herpes variant (OsHV-1 $\mu$ var) with no associated mortality in French-origin Pacific cupped oyster Crassostrea gigas farmed in Italy
}

\author{
William G. Dundon ${ }^{a}{ }^{*}$, Isabelle Arzul ${ }^{b}$, Emmanuelle Omnes ${ }^{b}$, Maeva Robert ${ }^{b}$, Cristian Magnabosco ${ }^{c}$, \\ Michela Zambon ${ }^{c}$, Lorenzo Gennari ${ }^{\mathrm{d}}$, Anna Toffan ${ }^{\mathrm{a}}$, Calogero Terregino ${ }^{\mathrm{a}}$, Ilaria Capua ${ }^{\mathrm{a}}$ and Giuseppe \\ Arcangeli
}

${ }^{a}$ Research and Development Department, Istituto Zooprofilattico Sperimentale delle Venezie, Legnaro (PD), Italy

IFREMER, Laboratoíre de Génétique et Pathologie, La Tremblade, France

${ }^{c}$ National Reference Center for Fish, Molluscs and Crustaceans diseases, Istituto Zooprofilattico Sperimentale delle Venezie, Adria (RO), Italy

Marine Biologist Consultant, Perugia, Italy

*: Corresponding author : William G. Dundon, Tel.: + 390498084390 ; fax: + 390498084360 ., email adress : wdundon@izsvenezie.it

\begin{abstract}
:
In April 2010, the sampling of juvenile Pacific cupped oysters originating from France was undertaken from a farm located off the coast of the Marche region in Italy. Samples were sent to the national reference laboratory for mollusc diseases for bacteriological, histological, electron microscopical and molecular analysis. Classical and Real-Time PCR indicated the presence of the microvariant (OsHV-1 $\mu v a r$ ) of Type 1 Ostreid Herpes virus (OsHV-1) despite the absence of clinical and pathological signs normally associated with the presence of this variant. Further molecular and sequencing analysis revealed the presence of OsHV-1 $\mu$ var and OsHV-1 DNA in one oyster indicating that simultaneous detection of both viruses is possible. This is the first report of the presence of OsHV-1 $\mu$ var in Italy and also the first time that evidence of possible co-infection of OsHV-1 and OsHV-1 $\mu$ var has been provided.
\end{abstract}

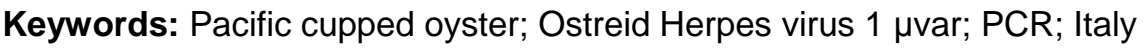




\section{Introduction}

Since 2008, the European aquaculture industry has experienced high mortality rates of up to $80 \%$ in the Pacific cupped oyster Crassostrea gigas. Between 20 to 100\% of breeding Pacific cupped oysters in some French farms and hatcheries have been affected while more recently significant increases in mortality have also been reported in Ireland, the UK and New Zealand (EFSA Panel on Animal Health and Welfare, 2010).

This high mortality in C. gigas has been shown to be associated with a new genotype of the Type 1 Ostreid Herpes virus (OsHV-1), referred to as OsHV-1 $\mu$ var (Segarra et al, 2010). OsHV-1 is a member of the Family Herpesviridae known to infect a variety of different oyster, clam and scallop species (Farley et al, 1972, Renault et al, 2004). Recently, it was proposed to include OsHV-1 in the newly created family Malacoherpesviridae in the order Herpesvirales (Davison et al, 2009). The Ostreid Herpes virus variant, OsHV-1 $\mu$ var, is defined on the basis of partial sequence data exhibiting a systematic deletion of 12 base pairs in ORF 4 of the genome in comparison with OsHV-1 (GenBank \# AY509253). The OsHV-1 $\mu$ var genotype was identified in $40 \%$ and $100 \%$ of French spat samples in 2008 and 2009 respectively (Segarra et al, 2010). In addition it has been reported that in experimental transmission studies, 100\% mortality has been observed following intra-muscular inoculation of OsHV-1 $\mu$ var in C. gigas spat (Segarra et al, 2010). Given the economic importance of oyster aquaculture in many European countries, the EU Commission Regulation n. 175/2010 was enacted in March 2010 to identify the presence of OsHV-1 $\mu$ var associated with mortality in oysters in order to reduce the spread of the virus to uninfected regions. According to the regulation, disease control measures must be implemented which include the establishment of containment areas and the restriction of movement from these areas if OsHV-1 $\mu v a r$ and accompanying mortality is identified.

Mortality associated with OsHV-1 is primarily observed among oysters less than one year of age and following an increase in water temperature (Burge et al, 2006; Sauvage et al. 2009). Prior to death no gross pathological lesions are detected among the oysters while the main histological lesions observed consist of large enlarged and abnormally shaped nuclei and abnormal chromatin patterns throughout the connective tissue (Renault et al, 1994a, 1995).

In April 2010, samples of juvenile C. gigas originating in France were sent to the Italian national reference for mollusc diseases for testing. Given the origin of the oysters and the recent EU regulation, an analysis for OsHV-1 $\mu$ var was undertaken. The results of these analyses are presented in this work.

\section{Materials and Methods}

\subsection{Samples}

Juvenile oysters originating from France were collected from a farm located 1.9 miles off the coast of the Marche region in Italy $\left(43^{\circ} 25^{\prime} \mathrm{N} 13^{\circ} 43^{\prime} \mathrm{E}\right)$ at various time intervals beginning the $13^{\text {th }}$ of April 2010 and ending $12^{\text {th }}$ of October 2010 . The oysters were part of a batch $(n=30,000)$ that had been imported from a hatchery in France at six months of age and had spent one month in Italian waters prior to sampling. The oysters were farmed in plastic cages at a depth of 3 metres. Water temperatures at sampling were $15^{\circ} \mathrm{C}, 23^{\circ} \mathrm{C}$ and $18^{\circ} \mathrm{C}$ in April, July and October respectively. There were no other oyster or mollusc farms within $50 \mathrm{kms}$ of the sampled farm. 


\subsection{Microbiological and pathological examination}

Bacteriological, histological and electron microscopical analyses were performed using routine procedures with each oyster sample being processed with separate sterile dissection instruments as follows. For the bacteriological tests, 20 to $50 \mu$ of haemolymph was taken from each sample, plated on thiosulfate-citrate-bile salts-sucrose (TCBS) media for 48 to $72 \mathrm{hrs}$ at $22^{\circ} \mathrm{C}$. Colonies were then transferred to blood agar plates and incubated at $22^{\circ} \mathrm{C}$ for 24 to $48 \mathrm{hrs}$ and used for further classical tests including morphology, gram-stain, motility, oxidase production, catalase production, oxidation-fermentation test and Vibriostat O129 sensitivity (Buller, 2004). An API 20 E (C) bacterial identification system was also used to detect Vibrio spp. For PCR and electron microscopical examination, sections of the mantle $(-25 \mathrm{mg})$ were removed and then analysed as pools or singularly. For EM the samples were subjected to three freezing and thawing cycles at $20^{\circ} \mathrm{C}$ and centrifuged for 12 minutes at $1,500 \mathrm{~g}$. One hundred microlitres of supernatant were then centrifuged in an Airfuge ${ }^{\circledR}$ A100 ultracentrifuge at $90,000 \mathrm{~g}$ on a 200 mesh screen, stained with phosphotungstate acid, and observed under a Philips $208 \mathrm{~S} \otimes$ electron microscope. For PCR, DNA was isolated from pooled (five samples per pool) or individual samples using the QIAamp mini DNA kit (Qiagen) following the manufacture's instructions. For histology, sections of the remaining representative organ (5 $\mathrm{mm}$ thickness) of the oysters were excised and fixed in Carson liquid for 24-48 $\mathrm{h}$ and then preserved in ethanol (70\%). Next, samples were dehydrated, embedded in paraffin and $3 \mu \mathrm{m}$ histological sections were cut and stained with hematoxylin-eosin for observation by light microscopy.

\subsection{Molecular techniques}

Molecular analysis for OsHV-1 $\mu$ var was carried out according to EU Council Directive 175/2010. In brief, PCR was performed on samples using primers CF and CR (primers available upon request). The thermocycling parameters were an initial denaturation step at $94^{\circ} \mathrm{C}$ for 2 min followed by 35 cycles of $94^{\circ} \mathrm{C}$ for $1 \mathrm{~min}, 50^{\circ} \mathrm{C}$ for $1 \mathrm{~min}$ and $72^{\circ} \mathrm{C}$ for $1 \mathrm{~min}$. The reaction was terminated with a final elongation step of 5 min at $72^{\circ} \mathrm{C}$. PCR controls consisted of plasmid DNA containing either a cloned fragment from OsHV-1 or OsHV-1 $\mu$ var previously amplified using primers CF and CR.

Real-Time PCR was performed as described by Pépin et al 2008 using primers; HVDP-F: 5' -ATT GAT GAT GTG GAT AAT CTG TG - 3' and HVDP-R: 5'- GGT AAA TAC CAT TGG TCT TGT TCC -3' according to Webb et al, 2007. Amplification were performed using a Mx3000 Thermocycler (Stratagene) in a total volume of $25 \mu \mathrm{l}$. The PCR mix included $5 \mu \mathrm{l}$ of a dilution of the same extracted DNA sample used for the classical PCR while plasmid DNA containing cloned viral DNA was used as a positive control. Brilliant ${ }^{\circledR}$ SYBR ${ }^{\circledR}$ Green I PCR Master Mix (Stratagene) (12.5 $\mu$ l), $2.5 \mu \mathrm{l}$ of each diluted primer $(2 \mu \mathrm{M}$ final concentration) and $2.5 \mu \mathrm{l}$ of distilled water were also added. Real-time PCR analysis was performed in duplicate. Absolute quantification of copies of OsHV-1 DNA (copies/ $\mu$ ) was carried out by comparing $C_{t}$ values obtained with a standard curve using the Thermocycler software. The standard curve was prepared using standard viral DNA diluted serially $1: 10\left(10^{5}\right.$ to $10^{1}$ copies of viral DNA/ $\mu$ l) in duplicate.

Amplicons were sequenced directly using the BigDye ${ }^{\circledR}$ Terminator v3.1 cycle sequencing kit (Applied Biosystems). For the co-infection studies amplicons were cloned in pCR2.1 using the TA cloning kit (Invitrogen) and individual clones were sequenced. Sequences have been deposited in GenBank under accession numbers HQ917018-HQ917032. 


\section{Results}

Histological analysis of 30 oysters taken during the first sampling in April 2010 did not reveal any of the typical nuclear lesions associated with infection by OsHV-1 $\mu$ var (e.g. marginalized chromatin, eosinophilic inclusion bodies) and electron microscopy did not reveal the presence of herpes-like viruses in any of the samples tested. Only one of the 30 samples tested was tentatively positive for Vibrio spp..

The PCR analysis of six pools, P1 to P6 (i.e. 30 samples), from the first collection of $C$. gigas in April 2010 revealed a positive amplicon corresponding to $157 \mathrm{bp}$ in three of the pools. One of the amplicons was sequenced directly and a Blast analysis revealed homology with ORF4 of the complete genome of OsHV-1 (Genbank AY509253) ( Davison et al, 2005)

The individual samples ( $\mathrm{C} 1$ to $\mathrm{C} 10)$ making up the first two pools ( $\mathrm{P} 1$ and $\mathrm{P} 2$ ) were retested and amplicons of 157 bp were observed for samples C2, C6, C8, C9 and C10 respectively corresponding to the presence of OsHV-1 $\mu$ var DNA. In contrast, the amplicon for C3 was of 173 bp corresponding to the presence of OsHV-1 in the sample (Figure 1).

The PCR amplicons for samples C2, C3, C9 and C10 were cloned into pCR2.1 using the TA cloning kit (Invitrogen) and transformed into Escherichia coli following standard protocols. Between 20 and 40 clones were then retested by classical PCR using primers CF and CR. All of the clones tested from samples C2, C9 and C10 yielded PCR products that corresponded to the presence of OsHV-1 $\mu$ var DNA (i.e. an amplicon of 157 bp). For sample C3, however, 36 clones were retested of which 34 produced a PCR amplicon of $173 \mathrm{bp}$ and two clones showed PCR products of $157 \mathrm{bp}$. Sequencing was then performed on 3 to 5 clones per sample and analysed. Clones derived from C2 $(n=4), C 9(n=3)$ and C10 $(n=3)$ produced sequences showing 99 to $100 \%$ identity with OsHV-1 $\mu$ var (Figure 2). The sequences of three of the clones [C3 (\#1), C3 (\#2), C3 (\#3)] derived from sample C3 revealed sequences showing between 97 and 98.5\% identities with OsHV-1 while two clones [C3 (\#12), C3 (\#30)] were 100\% identical with OsHV-1 $\mu$ var. These data, therefore, reveal the presence of DNA from both OsHV-1 and OsHV-1 $\mu$ var in the same sample.

Samples C1 to C10 and P1 to P6 were also tested by Real Time-PCR to determine the viral load in each sample. Only six of the fifteen samples tested gave $\mathrm{Ct}$ values of less than 35 revealing low viral loads ranging from 2.14 to 9.92 viral copy numbers per $0.25 \mathrm{mg}$ of tissue (Table1).

In May, July and October 2010, samples $(n=30)$ were collected, weighed, pooled and processed by classical PCR only. The samples in May and July were positive for OsHV-1 $\mu$ var while those for October were negative (data not shown). Weight analysis of the samples revealed that the average meat and dry weight of the oysters increased from 2.78 to $8.06 \mathrm{~g}$ (190 \% increase) and 13.80 to $45.98 \mathrm{~g}$ (233\% increase) respectively from April to October indicating a normal growth rate and that, therefore, there was no clinical manifestation associated with the presence of the virus (Table 2).

\section{Discussion}

Due to the origin of these samples and the implementation of a recent EU regulation, C. gigas farmed for less than a month in Italy were tested for the first time for the presence of Ostreid Herpes virus microvariant. Our analysis has clearly identified the presence of DNA from this virus in C. gigas. This is the first report of OsHV-1 $\mu$ var in oysters cultivated in Italian waters. 
During the period of investigation an overall mortality of approximately $10 \%$ was reported among the oysters although an approximate increase of $20 \%$ was observed due to external fouling of the oyster cages by mussels (Mytilus spp.) in June (L. Gennari personal communication). A mortality of $10 \%$ is not considered abnormal for long-line cultivation of oysters so it would appear that the presence of OsHV-1 $\mu$ var did not result in the increased mortality that been observed in oysters in other European countries (EFSA Panel on Animal Health and Welfare, 2010).

The low viral load detected in the samples by Real-Time PCR could be a result of the phase of infection or could reflect a latent stage of the virus. This hypothesis does however need further investigation. Previous work by Pépin et al (2008) has shown that an average number of $1 \times 10^{3}$ viral DNA copies per milligram of tissue did not represent an infectious status associated with mortality. Therefore the very low viral copy numbers detected by Real-Time PCR of between 2.14 and 9.92 in healthy molluscs is in full agreement with the findings of Pépin et al (2008). Some authors have been able to identify herpes-like viruses by electron microscopy in moribund oysters (Renault, T, 1994b; Lipart, 2002; Segarra et al 2010). In our study this was not the case, and, again, is probably a result of low viral concentration in the sample.

Another interesting result from our study is that we report simultaneous detection of both OsHV-1 and OsHV-1 $\mu$ var in one of the samples for the first time. It is also of note that from the cloning analysis undertaken it would appear that there was more OsHV-1 virus present than OsHV-1 $\mu$ var. These observations should be taken into consideration when undertaking surveillance programmes for these viruses. However, it should also be pointed out that the molecular analysis of one of the samples revealed the presence of DNA only and not viable virus so further studies need to be carried out to determine whether both viruses can be viable in the same sample. In addition, it would also be of interest to determine the viral load of each virus in the same sample.

One of the samples (i.e. C10) gave a positive amplicon using classical PCR but was negative following Real-Time PCR. This indicates that there is not complete agreement between these two molecular techniques. Also of note is the fact that the analysis by classical PCR of pooled samples collected in October 2010 were negative for OsHV-1 $\mu$ var. Whether this was a false negative result due to a lack of sensitivity of the classical PCR method or an indication of the elimination of the virus from the oysters requires further investigation.

The oyster farming industry in Italy is small with only five farmers presently registered, four of which are located in the Adriatic sea. Of these five, four have been importing their juvenile stock since 2005 from French hatcheries. The stock usually arrives in Spring at six months of age.

Up until recently, primarily due to the competitive prices of French, Spanish and Dutch oysters, the Italian industry has been producing less than 500 tonnes per annum which is insufficient to satisfy national demand estimated at between 5,000 and 10,000 tonnes/year. However, there has been a growing interest in the potential of this business with a significant increase in importation of juveniles from French hatcheries already planned for the Spring of 2011. Indeed, data indicates that the growth of oysters in Italian waters is more rapid that those in Atlantic waters which is thought to be due to the location of farms in areas rich in phytoplankton. Weights of 60 to 80 grams can be reached within 24 months compared to 36 months in more northern European countries (Turolla 2006).

Due to this growing interest in the oyster farming industry in Italy together with the results obtained from this study and the increasing number of countries reporting OsHV-1 $\mu$ var associated mortality, it is of importance that surveillance and monitoring programs for diseases of molluscs are implemented both at a national level and on internationally traded molluscs. 


\section{Figures}

Figure 1 : Classical PCR results obtained using primers CF and CR.

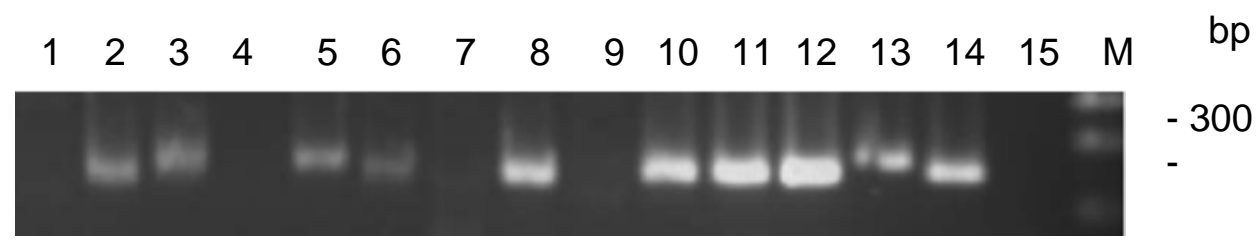

Lane 1: C1; 2: C2; 3: C3; 4: C4; 5: OsHV-1 positive control; 6: OsHV-1 $\mu$ var positive control; 7: C5; 8: C6; 9: C7; 10: C8; 11: C9; 12: C10; 13: OsHV-1 positive control; 14: OsHV-1 $\mu$ var positive control; 15: negative control;

Figure 2 : Nucleotide sequences of ORF4 generated from clones of PCR amplicons obtained from samples C2, C3, C9 and C10 using primers CF and CR. The region encompassing the $12 \mathrm{bp}$ deletion of ORF4 that distinguishes OsHV-1 from OsHV-1 $\mu$ var is shown in bold.

AY509253 GTTTTAAGACACTTTCCGACGTAAAAAAGTCATCATCATCATCATCATCATCATCTACGA C2(\#8) GTTTTAAGACACTTTCCGACGTAAAAA- G - - - - - - - - TCATCATCATCATCTACGA C3(\#12) GTTTTAAGACACTTTCCGACGTAAAAA C10(\#3) GTTTTAAGACACTTTCCGACGTAAAAAC10(\#2) GTTTTAAGACACTTTCCGACGTAAAAA-

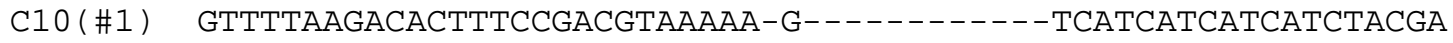
C9(\#3) GTTTTAAGACACTTTCCGACGTAAAAAC9(\#2) GTTTTAAGACACTTTCCGACGTAAAAAC9(\#1) GTTTTAAGACACTTTCCGACGTAAAAA- - - - - - - - - TCATCATCATCATCTACGA C2(\#24) GTTTTAAGACACTTTCCGACGTAAAAA- - - - - - - - - TCATCATCATCATCTACGA

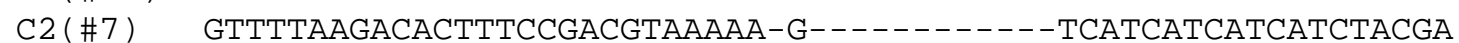
C2(\#1) GTTTTAAGACACTTTCCGACGTAAAAAC3(\#30) GTTTTAAGACACTTTCCGACGTAAAAA- - - - - - - - - - GCATCATCATCATCTACGA C3(\#1) GTTTTAAGACACTTTCCGACGTAAAAAAGTCATCATCATCATCATCATCATCATCTACGA C3(\#3) GTTTTAAGACACTTTCCGACGTAAAAAAGTCATCATCATCATCATCATCATCATCTACGA C3(\#2) GTTTTAAGACACTTTCCGACGTAAAAAAGTCATCATCATCATCATCATCATC - - TACGA $* * * * * * * * * * * * * * * * * * * * * * * * * * * * \quad * * * * * * * * * * \quad * * * * *$

AY509255 CAATTAAATCGTCAACACCATATGAGCTCTAACTCACACACCCATACTAAGATTTGACT C2(\#8) CAATTAAATCGTCAACACCATATGAGCTCTAACTCACA - - - CCATACTAAGATTTGACT C3(\#12) CAATTAAATCGTCAACACCATATGAGCTCTAACTCACA - - CCATACTAAGATTTGACT C10(\#3) CAATTAAATCGTCAACACCATATGAGCTCTAACTCACA - - - CCATACTAAGATTTGACT C10(\#2) CAATTAAATCGTCAACACCATATGAGCTCTAACTCACA - - CCATACTAAGATTTGACT C10(\#1) CAATTAAATCGTCAACACCATATGAGCTCTAACTCACA - - CCATACTAAGATTTGACT C9(\#3) CAATTAAATCGTCAACACCATATGAGCTCTAACTCACA - - - CCATACTAAGATTTGACT C9(\#2) CAATTAAATCGTCAACACCATATGAGCTCTAACTCACA - - - CCATACTAAGATTTGACT C9(\#1) CAATTAAATCGTCAACACCATATGAGCTCTAACTCACA - - CCATACTAAGATTTGACT C2(\#24) CAATTAAATCGTCAACACCATATGAGCTCTAACTCACA - - CCATACTAAGATTTGACT C2 (\#7) CAATTAAATCGTCAACACCATATGAGCTCTAACTCACA - - CCATACTAAGATTTGACT C2(\#1) CAATTAAATCGTCAACACCATATGAGCTCTAACTCACA - - CCATACTAAGATTTGACT C3(\#30) CAATTAAATCGTCAACACCATATGAGCTCTAACTCACA - - - CCATACTAAGATTTGACT C3(\#1) TAATTAAATCGTCAACACCATATGAGCTCTAACTCACAGC - CCATACTAAGATTTGACT C3(\#3) TAATTAAATCGTCAACACCATATGAGCTCTAACTCACAAC - CCATACTAAGATTTGACT C3(\#2) TAATTAAATCGTCAACACCATATGAGCTCTAACTCACAAC - CCATACTAAGATTTGACT 


\section{Tables}

Table 1 : Real-time PCR results on tested samples

\begin{tabular}{lcc}
\hline Sample & Real-Time Ct & Quantity (viral copies)/ $\mu l^{*}$ \\
\hline P1 & - & - \\
P2 & - & - \\
P3 & - & - \\
P4 & 34.68 & 2.24 \\
P5 & - & - \\
P6 & - & - \\
C1 & - & - \\
C2 & - & - \\
C3 & - & - \\
C4 & 34.35 & 2.77 \\
C5 & 34.75 & 2.14 \\
C6 & 33.36 & 5.22 \\
C7 & - & - \\
C8 & 34.58 & 2.38 \\
C9 & 32.35 & 9.92 \\
C10 & - & - \\
\hline & $* 25$ mg of mantle & \\
\hline & & \\
\hline & & \\
\hline & &
\end{tabular}

Table 2 : Data from collected samples

\begin{tabular}{llll} 
Sample date & Number of samples & Meat weight $(\mathbf{g})$ & Dry weight (g) \\
\hline $15 / 04 / 2010$ & 30 & $2.78 \pm 0.99$ & $13.80 \pm 4.40$ \\
$20 / 05 / 2010$ & 30 & $4.08 \pm 0.94$ & $15.87 \pm 3.25$ \\
$09 / 07 / 2010$ & 30 & $4.55 \pm 1.44$ & $26.64 \pm 7.01$ \\
$12 / 10 / 2010$ & 30 & $8.06 \pm 2.08$ & $45.98 \pm 11.97$ \\
\hline
\end{tabular}




\section{References}

EFSA Panel on Animal Health and welfare, 2010 - Scientific Opinion on the increased mortality events in Pacific oysters, Crassostrea gigas EFSA Journal 2010; 8, 1894, 1-60

EU regulation 175/2010 - implementing Council Directive 2006/88/EC as regards measures to control increased mortality in oysters of the species Crassostrea gigas in connection with the detection of Ostreid herpesvirus $1 \mu \mathrm{var}$ (OsHV-1 $\mu \mathrm{var}$ )

http://ec.europa.eu/food/animal/liveanimals/aquaculture/oyster mortalities en.htm

Buller, N.B., 2004. Bacteria from Fish and Other Aquatic Animals: A Practical Identification Manual. Cabi Publishing (UK) ISBN-10: 0851997384.

Burge, C.A., Griffin, F.J., Friedman, C.S., 2006. Mortality and herpesvirus infections of the Pacific oyster Crassostrea gigas in Tomales Bay, California, USA. Dis. Aquat. Org. 72, 31-43.

Davison, A.J., Trus, B.L., Cheng, N., Steven, A.C., Watson, M.S., Cunningham, C., Le Deuff, R.M., Renault, T., 2005. A novel class of herpesvirus with bivalve hosts. J Gen Virol. J86, 41-53.

Davison, A.J., Eberle, R., Ehlers, B., Hayward, G.S., McGeoch, D.J., Minson, A.C., Pellett, P.E., Roizman, B., Studdert, M.J., Thiry, E., 2009. The order Herpesvirales. Arch. Virol. 154, 171-177.

Farley, C.A., Banfield, W.G., Kasnic, G., Foster, W.S., 1972. Oyster herpes-type virus. Science 178, 759-760.

Lipart, C., Renault, T., 2002. Herpes-like virus detection in infected Crassostrea gigas spat using DIG labelled probes. J. Virol. Methods 101, 1-10.

Pépin, J.F., Riou, A., Renault, T., 2008. Rapid and sensitive detection of ostreid herpesvirus 1 in oyster samples by real-time PCR. J. Virol. Methods. 149, 269-276.

Renault, T., Le Deuff, R.M., Cochennec, N , Maffart, P., 1994a. Herpesvirus associated with mortalities among Pacific oyster, Crassostrea gigas, in France - comparative study. Revue de Médecine Vétèrinaire 145, 735-742.

Renault, T., Cochennec, N, Le Deuff, R.M., Chollet, B., 1994b. Herpes-like virus infecting Japanese oyster (Crassostrea gigas) spat. Bull. Eur. Ass. Fish Pathol. 14, 64-66.

Renault, T., Le Deuff, R.M., Cochennec, N., Chollet, B., Maffart, P., 1995. Herpes-like viruses associated with high mortality levels in larvae and spat of Pacific oysters, Crassostrea gigas: a comparative study, the thermal effects on virus detection in hatchery-reared larvae, reproduction of the disease in axenic larvae. Vet. Res. 26, 539-543.

Renault, T., Le Deuff, RM, Chollet, B, Cochennec, N, Gèrard, A., 2000. Concomitant herpes-like virus infections in hatchery-reared larvae and nursery-cultured spat Crassotrea gigas and Ostrea edulis. Dis. Aquatic Organisms 42, 173-183. 
Sauvage, C., Pépin, J.F., Lapègue, S., Boudry, P., Renault, T., 2009. Ostreid herpes virus 1 infection in families of the Pacific oyster, Crassostrea gigas, during a summer mortality outbreak: difference in viral DNA detection and quantification using real-time PCR, Virus Res. 142, 181-187.

Segarra, A., Pépin, J.F., Arzul, I., Morga, B., Faury, N., Renault, T., 2010. Detection and description of a particular Ostreid herpesvirus 1 genotype associated with massive mortality outbreaks of Pacific oysters, Crassostrea gigas, in France in 2008. Virus Res. 153, 92-99.

Turolla, E., 2006. Allevamento in sospensione dell'ostrica concava su sistemi long-line al largo di Goro (FE). II Pesce 3, http://www.pubblicitaitalia.com/ilpesce/2006/3/6731.html

Webb, S.C., Filder A., Renualt T., 2007. Primers for PCR-based detection of ostreid herpes virus-1 (OsHV-1): Application in a survey of New Zealand molluscs. Aquaculture, 272, 126-139. 